\title{
Mutagenic activation of biliary metabolites of benzo(a)pyrene by $\beta$-glucuronidase-positive bacteria in human faeces
}

\author{
M. NANNO,* M. MOROTOMI, H. TAKAYAMA, T. KUROSHIMA, R. TANAKA and M. MUTAI \\ Yakult Central Institute for Microbiological Research, Yaho 1796, Kunitachi, Tokyo 186, Japan
}

Summary. Human faeces hydrolysed synthetic $\beta$-D-glucuronides of both $p$-nitrophenol and phenolphthalein. The origin of this activity in faeces was localised in the bacterial pellet fraction after centrifugation. Ninety-seven bacterial strains with $\beta$-glucuronidase activity isolated from fresh human faeces were identified as species of Bacteroides, Peptostreptococcus, Fusobacterium, Propionibacterium, Clostridium, Eubacterium and Bifidobacterium. They were classified into two groups according to their activity against two synthetic $\beta$-D-glucuronides. One group hydrolysed $p$-nitrophenyl glucuronide and phenolphthalein glucuronide to the same extent and the other hydrolysed $p$-nitrophenyl glucuronide much more strongly than phenolphthalein glucuronide. The bile of rats given benzo(a)pyrene by mouth was tested for mutagenicity in the presence and absence of cell-free extracts of human faeces and bacteria. Extracts of $\beta$-glucuronidase-positive bacteria increased the mutagenicity of metabolites of benzo(a)pyrene, as did faecal extracts, but extracts of $\beta$-glucuronidasenegative bacteria did not. $D$-Saccharic acid-1, 4-lactone inhibited the increase in mutagenicity produced by the faecal extracts and extracts of $\beta$-glucuronidase-positive bacteria except for Peptostreptococcus strains 204 and 952. These results indicate that some intestinal bacteria have $\beta$-glucuronidases heterogenous in substrate specificity and that they may be involved in mutagenicity of benzo(a)pyrene in the intestinal tract.

\section{Introduction}

The intestinal tract has a large surface area and is constantly exposed to external influences including intestinal bacteria and their products. Epidemiological studies have shown that the incidence of colon cancer is higher in populations taking a Western diet, high in meat and fat and low in fibre. Although the effect of diet on intestinal bacteria is much more complex, it is known that high-meat or high-fat diets elevate $\beta$-glucuronidase activity in the intestinal contents and faeces (Reddy and Wynder, 1973; Reddy et al., 1974, 1977 and 1980; Goldin and Gorbach, 1976; Goldin et al., 1980). Some investigators therefore believe that $\beta$-glucuronidase in the intestinal tract is responsible for the hydrolysis of carcinogenic glucuronides, with resulting colon carcinogenesis (Bresnick, 1980). Kinoshita and Gelboin (1978) have demonstrated that $\beta$-glucuronidase produces activated inter-

* Present address: Department of Microbiology, Tohoku University, School of Dentistry, 4-1 Seiryo-machi, Sendai 980, Japan.

Received 18 Feb. 1986; accepted 7 Apr. 1986. mediates that bind to DNA during hydrolysis of benzo(a)pyrene-3-glucuronide. We have also found that $\beta$-glucuronidases in human faeces and some intestinal bacteria may be involved in the mutagenic activation of biliary metabolites of 1-nitropyrene (Morotomi et al., 1985). These results suggest that knowledge of the action of intestinal bacterial $\beta$-glucuronidases is necessary to assess the role of intestinal bacteria in colon carcinogenesis. We therefore investigated the ability of $\beta$-glucuronidase-positive bacteria isolated from human faeces to convert, in vitro, non-mutagenic metabolites of benzo(a)pyrene excreted into bile to mutagenic forms.

\section{Materials and methods}

\section{Collection and processing of faeces}

Samples of faeces from 22 healthy male adults taking a diet ad libitum were collected immediately after defaecation and transported to the laboratory for processing in strictly anaerobic conditions. One gram of each sample was transferred to $9 \mathrm{ml}$ of anaerobic diluent (Azuma and 
Suto. 1970) under oxygen-free $\mathrm{CO}_{2}$, thoroughly mixed, and further diluted with the anaerobic diluent. A suitably diluted sample was separated into two parts. One part was used to assay $\beta$-glucuronidase activity and the other for isolation of $\beta$-glucuronidase-positive bacteria. Faeces diluted $10^{\circ}$-fold $(0.1 \mathrm{ml})$ were cultivated anaerobically in a VL-G roll tube (Azuma and Suto, 1970) or on a GAM plate (Nissui Pharmaceutical Co. Lid. Japan) for 2 or 3 days. Colonies were selected at random and transferred into VL-G broth or GAM broth and, when fully grown. their $\beta$-glucuronidase activity was assayed. The identification of $\beta$-glucuronidase-positive bacteria was based on morphology. sensitivity to oxygen. and amounts of volatile and non-volatile fatty acids produced (Holdeman ef al. 1977). To determine the number of $\beta$-glucuronidase-positive bacteria in faeces, samples of faeces from four subjects were diluted serially and grown in the medium of Morotomi et al. (1981). When the inoculated bacteria had grown fully, the $\beta$-glucuronidase activity of each culture was assayed.

\section{B-Glucuronidase assay}

$\beta$-Glucuronidase activity was assayed with synthetic $\beta$-1)-glucuronides as substrates (Goldin and Gorbach. 1976). The reaction was started by adding $0.1 \mathrm{ml}$ of dilute facces or bacterial culture to $0.9 \mathrm{ml}$ of a reaction mixture containing $0.1 \mathrm{~mm}$ EDTA and $1 \mathrm{~mm} p$-nitrophenyl- $\beta$-Dglucuronide (Nakarai Chemicals Ltd, Japan) or phenolphthalein glucuronic acid (Sigma, St Louis, MO, USA) in $20 \mathrm{~mm}$ potassium-phosphate buffer $(p \mathrm{H} \mathrm{6.8})$. After incubation for $30 \mathrm{~min} 4 \mathrm{~h} .2 .5 \mathrm{ml}$ of $0.23 \mathrm{~m}$ glycine$\mathrm{NaOH}$ buffer containing $0.23 \mathrm{M} \mathrm{NaCl}(p \mathrm{H} 10.4)$ was added to the reaction mixture. which was then centrifuged at $1000 \mathrm{~g}$ for $30 \mathrm{~min}$ and the absorbance of the supernate at $400 \mathrm{~nm}$ (for $p$-nitrophenol) or $540 \mathrm{~nm}$ (for phenolphthalein) was measured. To determine the distribution of $\beta$-glucuronidases in faeces, dilute faeces was centrifuged at $1000 \mathrm{~g}$ for $30 \mathrm{~min}$ and $\beta$-glucuronidase activity of pellet and supernate were assayed separately. One unit (1U) was defined as the activity required to release $1 \mathrm{nmol}$ of $p$-nitrophenol or phenolphthalein in $1 \mathrm{~h}$.

\section{Preparation of faecal and hacterial extracts}

Fresh faeces from healthy male adults were homogenised with 9 volumes of cold $0.1 \mathrm{M}$ potassiumphosphate buffer $(p \mathrm{H} \mathrm{6.0)}$ and sonicated for 1 min with an Ultrasonic Disruptor (Model UR-200P, Tomy Seiko (o. Lid. Japan). The supernate after centrifugation at 10000 a for $30 \mathrm{~min}$ was sterilised by filtration through a 0. $4.5-\mu \mathrm{m}$ membrane (Millipore Corp., Bedford, MA, USA) and stored at - $20 \mathrm{C}$ until use. Bacteria were cultivated in GAM broth containing Tween $800.1 \%$ with or without sodium-glucuronate $0.5 \%$ at $37 \mathrm{C}$ for $16-48 \mathrm{~h}$. The suspensions were washed in cold $0.1 \mathrm{~m}$ potassiumphosphate buffer $(\mathrm{pH} 6.0)$ and treated in the same manner as faeces.

\section{Preparation of $B(a) P$-bile}

Fisher 344 male rats weighing about $250 \mathrm{~g}$ (Charles River, Japan) were given an oral dose of $25 \mathrm{mg}$ benzo(a)pyrene (Sigma) emulsified in $0.5 \mathrm{ml}$ of olive oil three times at intervals of $24 \mathrm{~h}$. Their bile was collected under pentobarbital anaesthesia for $6 \mathrm{~h}$ after the last dose. This bile (B(a)P-bile) was sterilised by filtration through a $0.45-\mu \mathrm{m}$ membrane (Millipore) and stored at $-20^{\circ} \mathrm{C}$ until use. Control bile was prepared in the same manner after administration of vehicle alone.

\section{Mutagenicity test}

The mutagenicity test of Ames et al. (1975) was used to detect an increase in mutagenicity of B(a)P-bile. The test strain, Salmonella typhimurium TA98, was grown in Nutrient Broth (Difco) and adjusted to $1.0 \times 10^{9} \mathrm{cfu} / \mathrm{ml}$. After incubating $0.1 \mathrm{ml}$ of B(a)P-bile with $0.1 \mathrm{ml}$ of faecal or bacterial extract with $0.1 \mathrm{ml}$ of $60 \mathrm{~mm} \mathrm{D}$-saccharic acid-1, 4-lactone (Sigma) in $0.1 \mathrm{M}$ potassium-phosphate buffer $(p \mathrm{H} 6.0)$ or $0.1 \mathrm{ml}$ of $0.1 \mathrm{M}$ potassium-phosphate buffer $(p \mathrm{H} \mathrm{6.0)}$ at $37 \mathrm{C}$ for $2 \mathrm{~h}, 0.1 \mathrm{ml}$ of $S$. typhimurium TA98 suspension $\left(1.0 \times 10^{8} \mathrm{cfu}\right)$ was added to the reaction mixture and incubation was continued for another $20 \mathrm{~min}$. Each incubation mixture was mixed with $2 \mathrm{ml}$ of $\mathrm{NaCl} 0.6 \%$ containing agar $0.7 \%$ and plated on minimal glucose-agar-medium. Mutagenicity was expressed as the average number of revertant colonies on duplicate plates after growth for 2 days.

\section{Results}

Characterisation of $\beta$-glucuronidase activity in human faeces

There were large variations between individuals and from day to day in human faecal $\beta$-glucuronidase activity but all faeces hydrolysed synthetic $\beta$-D-glucuronides of both $p$-nitrophenol and phenolphthalein (figure). When diluted faeces were centrifuged, almost all the activity $(85 \pm 8 \%, n=4)$ was localised in the bacterial pellet fraction. By limit dilution analysis, $\beta$-glucuronidase-positive bacteria were shown to be present at $>10^{\circ} \mathrm{g}$ of faeces (data not shown).

\section{Isolation of $\beta$-glucuronidase-positive bacteria from human faeces}

We screened 964 strains from the dominant bacteria of 33 fresh samples of faeces and isolated 99 $\beta$-glucuronidase-positive bacteria. Ninety-seven strains of these were identified as species of Bacteroides (66 strains), Peptostreptococcus (15 strains), Fusobacterium (7 strains), Propionibacterium (6 strains), Clostridium (1 strain), Eubacterium 


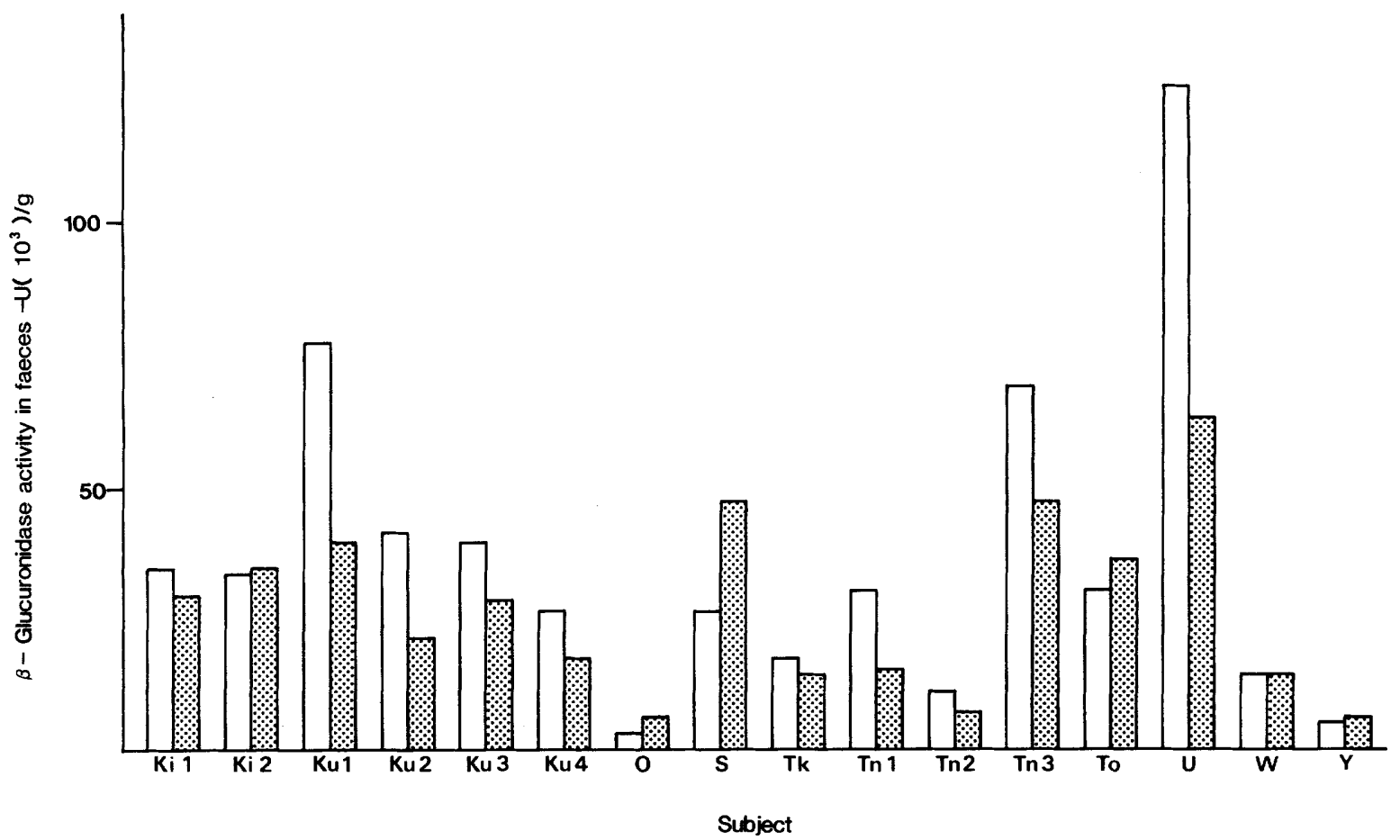

Figure. $\beta$-Glucuronidase activity in fresh human faeces. Each sample of faeces was diluted with the anaerobic diluent and its activity was assayed with p-nitrophenyl glucuronide $(\square)$ and phenolphthalein glucuronide $(\square)$. Numbers against subjects indicate that samples were collected from the same subjects on different days.

(1 strain) and Bifidobacterium (1 strain); two other strains were lost during identification. Fourteen strains with $\beta$-glucuronidase activity, were chosen for quantitative assay of activity. Seven strains hydrolysed $p$-nitrophenyl glucuronide and phenolphthalein glucuronide to the same extent and the other seven hydrolysed $p$-nitrophenyl glucuronide much more strongly than phenolphthalein glucuronide (table I).

Mutagenic activation of $B(a) P$-bile by $\beta$-glucuronidase-positive bacteria

The effects of cell-free extracts of $\beta$-glucuronidase-positive bacteria on the mutagenicity of B(a)P-bile were examined. Incubation of B(a)P-bile with extracts of faeces produced an increase in mutagenicity that depended on the dose of extract; the increase was completely abolished by heattreatment of the extract (data not shown). However, the mutagenicity of control bile, which was similar to that of untreated B(a)P-bile, remained unchanged after incubation with faeces extract (data not shown). Extracts of $\beta$-glucuronidasepositive bacteria produced an increase in the mutagenicity of $\mathrm{B}(\mathrm{a}) \mathrm{P}$-bile but those of $\beta$-glucuronidasenegative bacteria did not (table II). Furthermore,
Table I. $\beta$-Glucuronidase activity of human intestinal bacteria

\begin{tabular}{|c|c|c|c|}
\hline \multirow[b]{2}{*}{ Strain } & \multirow[b]{2}{*}{ Subject } & \multicolumn{2}{|c|}{$\begin{array}{c}\beta \text {-Glucuronidase activity* } \\
(\mathrm{U} / \mathrm{mg} \text { protein })\end{array}$} \\
\hline & & $\begin{array}{c}\text { against } \\
\text { PNPGA } \dagger\end{array}$ & $\begin{array}{l}\text { against } \\
\text { PGA }\end{array}$ \\
\hline Bacteroides sp. 265 & Ms & 50 & 48 \\
\hline Bacteroides sp. 814 & $\mathrm{Ki}$ & 19 & 37 \\
\hline Peptostreptococcus sp. 204 & $\mathrm{~S}$ & 7800 & 4880 \\
\hline Peptostreptococcus sp. 952 & $\mathrm{O}$ & 6290 & 3780 \\
\hline Clostridium sp. 185 & $\mathrm{Ku}$ & 15000 & 16000 \\
\hline Eubacterium sp. 86 & A & 1540 & 1130 \\
\hline Fusobacterium sp. 823 & $\mathbf{K i}$ & 58 & 78 \\
\hline Bacteroides sp. 43 & $\mathrm{U}$ & 106 & ND \\
\hline Bacteroides sp. 239 & S & 137 & 15 \\
\hline Bacteroides sp. 295 & $\mathbf{W}$ & 119 & ND \\
\hline Bacteroides sp. 332 & $\mathrm{Tn}$ & 60 & $<1$ \\
\hline Bacteroides sp. 521 & Ms & 201 & 18 \\
\hline Bacteroides sp. 543 & Ms & 92 & ND \\
\hline Bacteroides sp. 768 & $\mathrm{Mt}$ & 165 & 15 \\
\hline
\end{tabular}

PNPGA, p-nitrophenyl glucuronide; PGA, phenolphthalein glucuronide; ND, not detected.

* The value is the mean of two separate experiments.

$20 \mathrm{~mm}$ D-saccharic acid-1, 4-lactone, which completely inhibited $\beta$-glucuronidase activity against $p$-nitrophenyl glucuronide of the bacterial extracts, 
Table II. Mutagenic activation of benzo(a)pyrene-bile by the extracts of faeces and $\beta$-glucuronidase-positive bacteria

\begin{tabular}{|c|c|c|c|c|c|}
\hline & \multirow[b]{2}{*}{ Extracts derived from } & \multicolumn{2}{|c|}{$\begin{array}{c}\beta-\text { Glucuronidase activity* } \\
\text { (U plate) }\end{array}$} & \multicolumn{2}{|c|}{$\begin{array}{l}\text { Mutagenicity of B(a)P-bilet } \\
\text { (number of colonies/plate) }\end{array}$} \\
\hline & & - & + & - & + \\
\hline \multirow[t]{14}{*}{ Expt 1} & Control & - & - & 43 & 48 \\
\hline & Faeces $\mathrm{Ku}$ & NT & NT & 248 & 171 \\
\hline & Facces Mt & NT & NT & 203 & 128 \\
\hline & Faeces $\mathrm{Tk}$ & NT & NT & 179 & 151 \\
\hline & Faeces U & NT & NT & 233 & 149 \\
\hline & Peprostroprococess sp. 204 & 472 & 0 & 145 & 142 \\
\hline & Péptestreptococetss sp. 952 & 460 & 0 & 148 & 117 \\
\hline & Clustridium sp. 185 & 480 & 0 & 146 & 69 \\
\hline & Euhacterium sp. 86 & 191 & 0 & 128 & 64 \\
\hline & Bacteroides sp. 43 & 44 & 0 & 207 & 57 \\
\hline & Bacteroides sp. 295 & 100 & 0 & 189 & 81 \\
\hline & Bacteroides sp. 521 & 70 & 0 & 200 & 59 \\
\hline & Bacteroides sp. 768 & 42 & 0 & 173 & 50 \\
\hline & E. coli $\beta$-glucuronidase + & 479 & 0 & 123 & 69 \\
\hline \multirow[t]{4}{*}{ Expt. 2} & Control & - & - & 21 & 25 \\
\hline & Peptosireptococicus sp. 952 & 460 & 0 & 85 & 77 \\
\hline & Bifidobacterium hifidum YIT4007 & 0 & NT & 25 & NT \\
\hline & Streptococcus faccalis ATCC 19433 & 0 & NT & 25 & NT \\
\hline
\end{tabular}

NT, not tested.

* $\beta$-Glucuronidase activity was assayed with $p$-nitrophenyl glucuronide in the absence $(-)$ or presence $(+)$ of $20 \mathrm{~mm}$ D-saccharic acid-1. 4-lactone.

$\rightarrow$ Different lots of $\mathrm{B}(\mathrm{a}) \mathrm{P}$-biles were used in experiment 1 and experiment 2. Mutagenicity was expressed as the number of revertant colonies formed in the absence $(-)$ or presence $(+)$ of $20 \mathrm{~mm} \mathrm{D-saccharic} \mathrm{acid-1,}$ 4-lactone.

${ }_{+}$Purified E. coli $\beta$-glucuronidase (Sigma, G-3510) was used.

inhibited the increase in mutagenicity produced by the extracts of bacteria except for Peptostreptococcus strains 204 and 952 (table II).

\section{Discussion}

$\beta$-Glucuronidase activity in faeces has been assayed usually with the synthetic $\beta$-D-glucuronides of $p$-nitrophenol or phenolphthalein because of their availability but it is poorly understood whether this enzyme can hydrolyse native glucuronides excreted in the form of bile into the intestinal tract. Since, on the basis of comparison between germfree and conventional rats (Rød and Midtvedt, 1977) and our fractionation analysis, the major origin of intestinal $\beta$-glucuronidase activity is thought to be intestinal bacteria, we isolated $\beta$-glucuronidase-positive bacteria from the dominant flora of fresh human faeces. One group of bacteria hydrolysed the two synthetic $\beta$-1 -glucuronides to the same extent and the other hydrolysed $p$-nitrophenyl glucuronide much more strongly than phenolphthalcin glucuronide; this activity is similar to that of purified Escherichia coli $\beta$-glucuronidase (Tomašic and Keglević, 1973).
Monocontamination of germfree rats with $E$. coli gave intestinal $\beta$-glucuronidase activity corresponding to that of conventional rats ( $\operatorname{c} ø \mathrm{~d}$ and Midtvedt, 1977). However, in the case of human faeces, $E$. coli is not the major origin of faecal $\beta$-glucuronidase activity because faeces hydrolyse phenolphthalein glucuronide as well as $p$-nitrophenyl glucuronide (figure). The reason for this discrepancy is unclear. Because Rød and Midtvedt (1977) used only p-nitrophenyl glucuronide as substrate, it is necessary to compare intestinal $\beta$-glucuronidase activity of conventional and E. coli-monocontaminated rats against other substrates. Our results suggest that at least two types of $\beta$-glucuronidases derived from anaerobic bacteria may be responsible for human faecal $\beta$-glucuronidase activity.

It is of particular interest to know whether these bacterial $\beta$-glucuronidases can hydrolyse native glucuronides. Although human faeces and several intestinal bacteria are known to hydrolyse the conjugates of benzo(a)pyrene excreted in the bile of rats (Renwick and Drasar, 1976), the properties of enzymes responsible for the deconjugation have not been investigated. We confirmed that the 
extracts of $\beta$-glucuronidase-positive bacteria produced an increase in mutagenicity of B(a)P-bile and those of $\beta$-glucuronidase-negative bacteria did not but a correlation between the activity against $p$-nitrophenyl glucuronide and the increase in mutagenicity was not detected. Extracts of faeces and of $\beta$-glucuronidase-positive bacteria except for Peptostreptococcus strains 204 and 952 produced an increase in mutagenicity inhibited by D-saccharic acid-1, 4-lactone. Because this reagent completely inhibited $\beta$-glucuronidase activity against $p$-nitrophenyl glucuronide (table II) and phenolphthalein glucuronide (data not shown) of the extracts of Peptostreptococcus strains 204 and 952 , it is unlikely that their mutagenic activity resides in a $\beta$-glucuronidase active specifically against phenolphthalein glucuronide. Therefore, we think that involvement of bacterial $\beta$-glucuronidases in the mutagenic activation of $\mathrm{B}(\mathrm{a}) \mathrm{P}$-bile is not uniform and $\beta$-glucuronidases from Peptostrepto-

\section{REFERENCES}

Ames B N, McCann J, Yamasaki E 1975 Methods for detecting carcinogens and mutagens with the Salmonella/mammalian-microsome mutagenicity test. Mutation Research 31: 347-364.

Azuma R, Suto T 1970 Validity of transfer of the taxonomical position of Corynebacterium pseudopyogenes from genus Corynebacterium to genus Actinomyces. In: Iizuka H, Hasegawa $T$ (eds) Proceedings of the first international conference on culture collections. University Park Press, Baltimore, MD, pp 493-505.

Bresnick E 1980 Colon carcinogenesis. Cancer 45:1047-1051.

Goldin B R, Gorbach S L 1976 The relationship between diet and rat fecal bacterial enzymes implicated in colon cancer. Journal of National Cancer Institute 57:371-375.

Goldin B R, Swenson L, Dwyer J, Sexton M, Gorbach S L 1980 Effect of diet and Lactobacillus acidophilus supplements on human fecal bacterial enzymes. Journal of National Cancer Institute 64:255-261.

Holdeman L V, Cato E P, Moore W E C 1977 Anaerobe laboratory manual, 4th edn. Virginia Polytechnic Institute and State University, Blacksburg, VA.

Kinoshita N, Gelboin H V $1978 \beta$-Glucuronidase catalyzed hydrolysis of benzo(a)pyrene-3-glucuronide and binding to DNA. Science 199:307-309.

Morotomi M, Takayama H, Nanno M, Tanaka R, Kawai Y, Mutai M 1981 Significance of fecal medium for human intestinal microflora. In: Sasaki $\mathrm{S}$ et al. (eds) Recent advances in germfree research. Proceedings of the 7 th international symposium on gnotobiology. Tokai University Press, Tokyo, Japan, pp 293-301. coccus strains 204 and 952 may not activate $\mathrm{B}(\mathrm{a}) \mathrm{P}$-bile, in spite of their high activity against synthetic $\beta$-D-glucuronides. Studies with purified $\beta$-glucuronidases will clarify these points. Furthermore, it is important to determine whether the glucuronides can be transported into intact bacteria and hydrolysed by their $\beta$-glucuronidases. Synthetic $\beta$-D-glucuronides are thought to be transported into intact bacteria because they can be hydrolysed by washed intact bacteria. Biochemical analysis of $\mathrm{B}(\mathrm{a}) \mathrm{P}$-bile before and after treatment with the intact $\beta$-glucuronidase-positive bacteria in place of their cell-free extracts will resolve the problem about the transport. We conclude that some intestinal $\beta$-glucuronidase-positive bacteria can activate non-mutagenic metabolites of benzo(a)pyrene in vitro.

We thank Mrs Sachiko Sekiguchi and Mrs Noriko Matsuzaki-Sasaki for their skilled technical assistance.
Morotomi M, Nanno M, Watanabe T, Sakurai T, Mutai M 1985 Mutagenic activation of biliary metabolites of 1-nitropyrene by intestinal microflora. Mutation Research 149: 171-178.

Reddy B S, Wynder E L 1973 Large-bowel carcinogenesis: fecal constituents of populations with diverse incidence rates of colon cancer. Journal of National Cancer Institute 50:14371442.

Reddy B S, Weisburger J H, Wynder E L 1974 Fecal bacterial $\beta$ glucuronidase: control by diet. Science 183: 416-417.

Reddy B S, Mangat S, Weisburger J H, Wynder E L 1977 Effect of high-risk diets for colon carcinogenesis on intestinal mucosal and bacterial $\beta$-glucuronidase activity in F344 rats. Cancer Research 37:3533-3536.

Reddy B S, Hanson D, Mangat S, Mathews L, Sbaschnig M, Sharma C, Simi B 1980 Effect of high-fat, high-beef diet and of mode of cooking of beef in the diet on fecal bacterial enzymes and fecal bile acids and neutral sterols. Journal of Nutrition 110:1880-1887.

Renwick A G, Drasar B S 1976 Environmental carcinogens and large bowel cancer. Nature 263:234-235.

Rød T O, Midtvedt T 1977 Origin of intestinal $\beta$-glucuronidase in germfree, monocontaminated and conventional rats. Acta Pathologica et Microbiologica Scandinavica Section B 85:271-276.

Tomašić J, Keglević D 1973 The kinetics of hydrolysis of synthetic glucuronic esters and glucuronic ethers by bovine liver and Escherichia coli $\beta$-glucuronidase. Biochemical Journal 133:789-795. 